\title{
Regulasi, Komitmen Organisasi, Sumber Daya Manusia, dan Pengelolaan Keuangan Desa terhadap Kinerja Pemerintah Desa
}

\author{
Norma Fitria \\ normafitria21@gmail.com \\ Akuntansi, Fakultas Ekonomi, \\ Universitas Merdeka Madiun, Madiun, Indonesia \\ Nurharibnu Wibisono \\ nurharibnu@ unmer-madiun.ac.id \\ Akuntansi, Fakultas Ekonomi, \\ Universitas Merdeka Madiun, Madiun, Indonesia
}

\begin{abstract}
This research aims to analyse the factors that influence the local government management performance towards the local government financial management by using an intervening variable. The subjects of this study were the village head, village secretary, introductory village, financial officer and operator of finance in the village located in Madiun District, Madiun Regency. The samples of this study were 60 respondents using a saturated sample (census). The test results show that the regulation and human resources have significant positive effect on local government financial management. Yet, organizational commitment does not involve village financial management. Human resources positively influence the performance of local government management, while regulations and organizational commitment do not support the performance of local government management. Local government financial management variables support the positive performance of the local government performance.
\end{abstract}

Keywords: regulation, organizational commitment, human resources, village financial management, village government performance

\begin{abstract}
Abstrak
Penelitian ini bertujuan untuk mengetahui faktor-faktor yang mempengaruhi kinerja pemerintah desa terhadap pengelolaan keuangan desa melalui variabel intervening. Subyek penelitian ini adalah kepala desa, sekretaris desa, bendahara desa, kaur keuangan dan operator bagian keuangan di Desa yang berada di Kecamatan Madiun, Kabupaten Madiun. Sampel penelitian ini adalah 60 responden menggunakan sample jenuh (sensus). Hasil pengujian menunjukkan bahwa regulasi dan sumber daya manusia berpengaruh signifikan positif terhadap pengelolaan keuangan desa. Sedangkan komitmen organisasi tidak berpengaruh terhadap pengelolaan keuangan desa. Sumber daya manusia berpengaruh positif terhadap kinerja pemerintah desa, sedangkan regulasi dan komitmen organisasi tidak berpengaruh terhadap kinerja pemerintah desa. Variabel pengelolaan keuangan desa berpengaruh positif terhadap kinerja pemerintah desa.
\end{abstract}

Kata kunci : regulasi, komitmen organisasi, sumber daya manusia, pengelolaan keuangan desa, kinerja pemerintah desa 


\section{PENDAHULUAN}

Otonomi daerah yang luas sesuai Undang-Undang No. 32, 2004, terutama Kabupaten dan Kota memberikan wewenange untuk mengembalikan harkat dan martabat masyarakat di desa. Selain itu, UU tersebut juga memberikan manfaat seperti pendidikan politik untuk peningkatan kualitas demokrasi, efisiensi pelayanan public, percepatan pembangunan daerah dan menciptakan cara berpemerintahan yang baik. Kebijakan ini membuat desa sebagai subsistem pemerintahan terendah secara nasional sehingga, desa memerlukan adaptasi dan antisipasi terhadap perkembangan yang ada (Solekhan, 2014: 8-9).

Dalam mengatur dan mengurus kepentingan masyarakatnya sesuai nilai sosial budaya, adat istiadat, mengelola kelembagaan desa dan asal usul, pemerintah desa diberikan otonomi. Pemerintah desa setiap taunnya mendapatkan kucuran dana dari pemerintah untuk keberlangsungan otonominya. Kucuran dana tersebut telah diatur dalam Peraturan Pemerintah No. 60, 2014, sehingga dana desa bersumber dari APBN (Anggaran Pendapatan dan Belanja Negara) dan ditransfer ke APD/K (Anggaran Pendapatan Daerah Kabupaten/Kota). Dana tersebut akan digunakan untuk membiayai kebutuhan desa. Pemberian dana desa ini bertujuan untuk memberkan pelayanan prima dalam program pembangunan baik fisik maupun non fisik, dibutuhkan kinerja pemerintah desa yang baik untuk mengelola keuangan desa yang baik pula.

Sesuai dengan agenda prioritas (Nawacita) pemerintah yang ada di dalam Rencana Jangka Menengah Nasional 2015-2019 (Bappenas, 2014), yakni "Membangun Indonesia dari pinggiran dengan memperkuat daerah-daerah dan desa dalam kerangka negara kesatuan". Menurut Menteri Desa, Pembangunann Daerah Tertinggal dan Transmigasi (Mendes PDTT), dana desa memberikan efek ekonomi yang besar bagi masyarakat desa. Jumlah Dana Desa yang tahun 2018 mencapai Rp 60 Triliun (sampai Rp 100 trilliun) (Kompas, 2018). Hal ini sejalan dengan (Sunarti, 2018) yang menyatakan bahwa penggunaan Dana desa dalam pengelolaan keuangan desa memiliki pengaruh yang signifika terhadap kinerja suatu instansi.

Di lain sisi, Pemerintah Kabupaten Madiun pernah menduduki peringkat 7 daerah tertinggal di Jawa Timur berdasarkan beberapa kriteria yang berlaku. Oleh sebabnya, penelitian ini menganalisis sebab akibat dari pengaruh regulasi terhadap pengelolaan keuangan desa, komitmen organisasi terhadap pengelolaan keuangan desa, sumber daya manusia terhadap pengelolaan keuangan desa, regulasi terhadap kinerja pemerintah desa, komitmen organisasi terhadap kinerja pemerintah desa, sumber daya manusia terhadap kinerja pemerintah desa dan pengelolaan keuangan desa terhadap kinerja pemerintah desa. Hubungan tersebut dimediasi oleh variabel intervening, yaitu, pengelolaan keuangan desa.

\section{TINJAUAN LITERATUR}

Penelitian ini meneliti tentang faktor-faktor yang memperngaruhi kinerja pada pemerintah desa melalui pengelolaan keuangan desa sebagai variabel intervening, dengan Regulasi (X1), Komitmen Organisasi (X2), Sumber Daya Manusia (X3), Kinerja (Y), Pengelolaan Keuangan Desa $(\mathrm{Z})$ dengan variabel intervening. Berikut kerangka persamaan analisis jalur. 


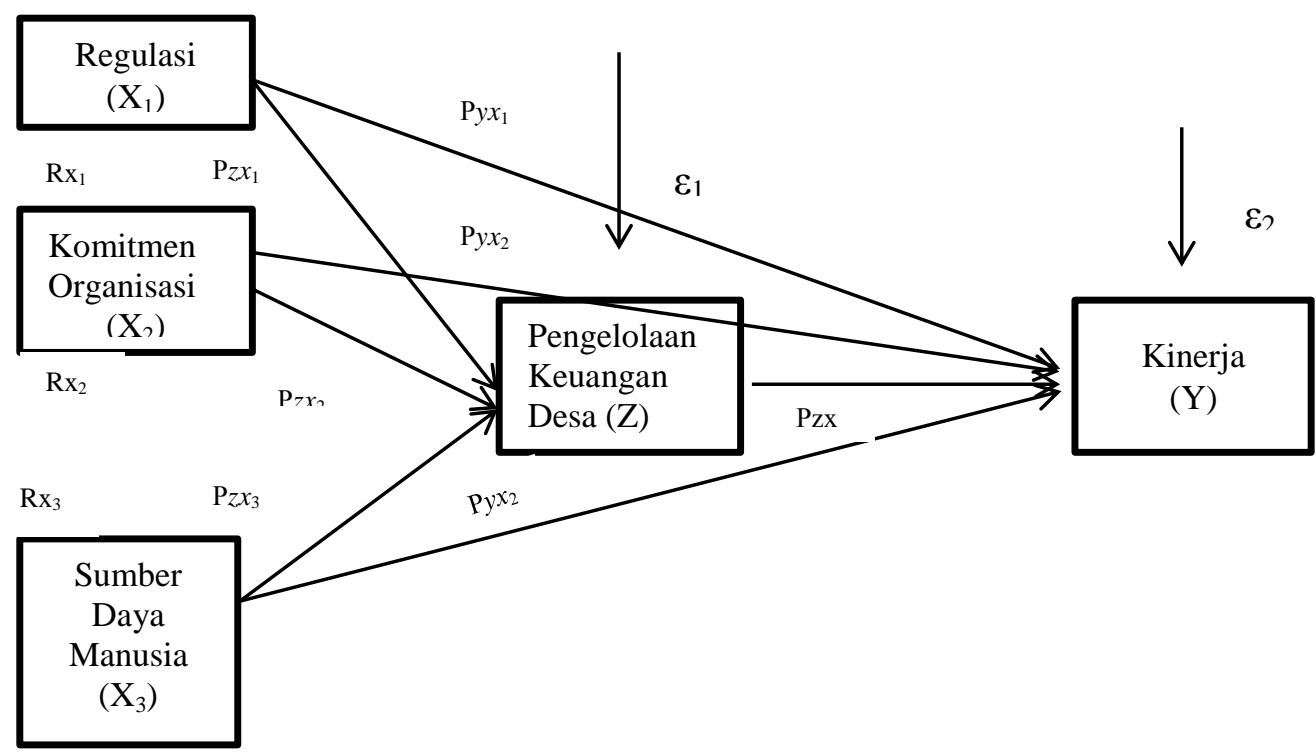

Gambar 1. Kerangka pemikiran (1)

$$
\mathrm{Y}=\rho z x_{1} \mathrm{X}_{1}+\rho z x_{2} \mathrm{X}_{2}+\rho z x_{3} \mathrm{X}_{3}+\varepsilon_{1}
$$

Keterangan:

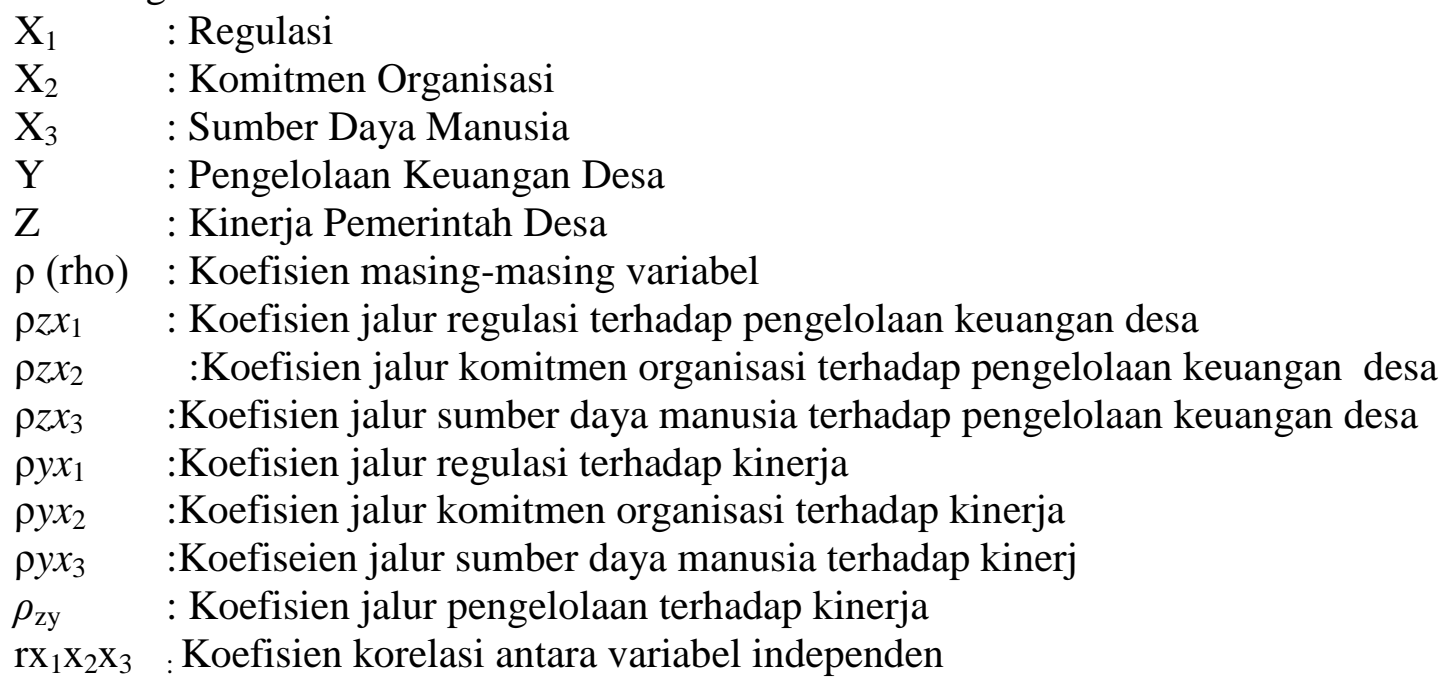
$\varepsilon$ (epsilon): Faktor lain yang mempengaruhi variabel dependen (diluar yang dipengaruhi yang tidak diteliti).

Berdasarkan uraian kerangka diatas, penelitian ini bertujuan untuk menguji dan menganalisis faktor-faktor yang mempengaruhi kinerja pemerintah desa terutama melalui pengelolaan keuangan desa. Adapun hipotesinya sebagai berikut.

Peraturan perundang-undangan adalah peraturan tertulis yang memuat norma hukum yang mengikat secara umum dan dibentuk atau ditetapkan oleh lembaga negara atau pejabat yang berwenang melalui prosedur yang ditetapkan dalam peraturan perundang-undangan (UU No 12 Tahun 2011). Reformasi politik di Indonesia telah mengubah sistem kehidupan negara. Pemisahan kekuasaan antara eksekutif, yudikatif, dan legislatif dilaksanakan. Selain itu, partisipasi masyarakat akan mendorong praktik demokrasi dalam pelaksanaan akuntabilitas publik yang sesuai dengan otonomi daerah. UU no 22 Tahun 1999 tentang 
Pemerintah Daerah dan UU No 25Tahun 1999 tentang Perimbangan Keuangan Pusat dan Daerah merupakan 2 undang- undang yang berupaya mewujudkan otonomi daerah yang lebih luas ( Bastian, 2005: 51). Haryanto, 2007; 22 menjelaskan bahwa Regulasi berperan penting dalam proses keuangan desa secara keseluruhan. Dengan regulasi dari berbagai UndangUndang yang bertujuan agar memudahkan dalam pelaksanaannya dan tidak menimbulkan multitafsir dalam penerapannya. Regulasi ini dimaksudkan untuk memuat berbagai kebijakan terkait dengan perencanaan, pelaksanaan, penatausahaan, dan pertanggungjawaban keuangan desa. Pengelolaan keuangan desa merupakan subsistem dari sistem pengelolaan keuangan daerah dan negara serta merupakan elemen pokok dalam penyelenggaraan pemerintahan desa. Pengelolaan keuangan desa diatur dengan Undang- Undang Nomor 6 Tahun 2014 tentang Desa sampai Peraturan Daerah dan Peraturan Bupati/Walikota. Dengan adanya peraturan yang mengatur tentang desa dan pengelolaan keuangannya, diharapkan dapat meningkatkan pembangunan masyarakat desa, yang dimulai dengan melaksanakan pengelolaan keuangan desa yang lebih baik. Hasil Penelitian Rulyanti (2017) menyimpulkan bahwa regulasi tidak berpengaruh terhadap pengelolaan keuangan desa di Bondowoso. Aparatur desa masih megalami kesulitan dalam mengimplementasikan dan memahami berbagai bentuk peraturan yang dikeluarkan oleh Pemerintah Desa maupun Pemerintah Pusat, sehingga dalam menjalankan tugas fungsi dan pokoknya masih belum sepenuhnya menggunakan peraturan yang berlaku.

\section{$H_{1}$ : Regulasi tidak berpengaruh signifikan terhadap pengelolaan keuangan desa}

Yusuf dan Syarif, (2018:33) mengungkapkan komitmen organisasi menunjukkan keyakinan dan dukungan yang kuat terhadap nilai dan sasaran yang ingin dicapai oleh organisasi. Komitmen organisasi ada dalam diri suatu individu yang berguna sebagai penunjang keberhasilan suatu organisasi. Dengan adanya komitmen organisasi yang tinggi, kepala desa sebagai kedudukan yang paling tinggi dalam stuktur perangkat desa, dapat meningkatkan kualitas pengelolaan keuangan desa. Penelitian Rulyanti (2017) menguji tentang pengaruh komitmen organisasi terhadap pengelolaan keuangan desa, hasil yang diperoleh bahwa komitmen organisasi berpengaruh positif terhadap pengelolaan keuangan desa. Artinya pengelolaan keuangan desa yang efektif berasal dari komitmen organisasi yang tinggi dari perangkat desa. Dari penelitian Halim (2012) komitmen organisasi berpengaruh positif terhadap pengelolaan keuangan daerah. Perilaku, persepsi, dan sikap pegawai dalam melaksanakan pegelolaan keuangan desa.

\section{$\mathrm{H}_{2}$ : Komitmen organisasi berpengaruh signifikan positif terhadap pengelolaan keuangan desa}

Sumber daya manusia adalah kemampuan terpadu dari daya pikir dan daya fisik yang dimiliki individu. Perilaku dan sifatnya ditentukan oleh keturunan dan lingkungannya, sedangkan prestasi kerjanya di motivasi oleh keinginan untuk memenuhi kepuasannya (Priyono \& Marnis, 2008: 18). Sebagaimana dijelaskan bahwa dimensi pokok sumber daya manusia adalah kontribusinya terhadap organisasi, sedangkan dimensi pokok manusia adalah perlakuan kontribusi terhadapnya yang pada gilirannya akan menentukan kualitas dan kapabilitas hidupnya. Sugeng (2014) aparatur pemerintah desa tidak berpengaruh positif terhadap pengelolaan keuangan daerah. Hasil yang berbeda ditunjukkan oleh penelitian Rulyanti (2017) bahwa Sumber Daya Manusia berpengaruh signifikan positif, berarti peran aparatur desa dalam pengelolaan keuangan desa baik itu perencanaan, regulasi, pelaksanaan 
maupun penyusunan Keputusan Kepala Desa dan Peraturan Desa berjalan cukup baik.

$H_{3}$ : Sumber Daya Manusia berpengaruh signifikan positif terhadap pengelolaan keuangan desa

Sesuai dengan teori hierarki norma hukum oleh Hans Kelsen bahwa norma-norma hukum itu berjenjang-jenjang dan berlapis-lapis dalam suatu hierarki (tata susunan) dalam arti suatu norma yang lebih tinggi berlaku, bersumber dan berdasar pada norma yang lebih tinggi lagi, demikian seterusnya sampai pada suatu norma yang tidak dapat ditelusuri lebih lanjut dan bersifat hipotetis dan fiktif serta abstrak, yaitu Norma Dasar (Grundnorm), maka peraturan perundang-undangan ada yang mempunyai tingkatan yang tinggi dan ada yang mempunyai tingkatan lebih rendah. Adanya sekumpulan regulasi tentang pengelolaan keuangan desa, sangat berpengaruh terhadap kinerja pemerintah desa, dimana semakin tinggi aturan yang diterapan oleh perangkat desa maka akan meningkatkan kualitas kinerja perangkat desa. Penggunaan aturan merupakan salah satu faktor pendorong meningkatkan kualitas dan kuantitas kerja seseorang (Haryani dan Syafruddin, 2010).

\section{$\mathrm{H}_{4}$ : Regulasi berpengaruh signifikan terhadap positif kinerja}

Komitmen Organisasi merupakan keyakinan dan dukungan yang kuat terhadap nilai dan sasaran yang ingin dicapai oganisasi. Komitmen tidak ada hubungannya dengan bakat, kepintaran atau talenta (Warisno, 2009). Ada 3 komponen komitmen organisasi menurut Mayer et al (1993) yakni:

\section{Komitmen Afektif}

mengarah pada the employee's emotional attachment to, identification with, and involvement in the organization. Artinya komitmen afektif berkaitan dengan identifikasi karyawan, emosional karyawan dan keterlibatan karyawan pada organisasi. Karyawan yang memilki komitmen afektif yang kuat akan terus bekerja dalam organisasi karena mereka memang ingin melakukan hal tersebut.

\section{Komitmen Kontinyu}

Komitmen ini berkaitan dengan persepsi seseeorang atas biaya dan resiko dengan meninggalkan organisasi saat ini. Maknanya perasaan berat meninggalkan organisasi karena kebutuhan untuk bertahan.

\section{Komitmen Normatif}

Komitmen normatif berkiaitan dengan perasaan wajib untuk tetap bekerja dalam organisasi. Artinya karyawan yang memiliki komitmen normatif yang tinggi merasa bahwa mereka wajib bertahan dalam organisasi.

Hasil penelitian Warisno (2009) menunjukkan bahwa komitmen orgnisasi tidak berpengaruh positif terhadap kinerja pemerintah desa. Hasil ini bertolak belakang dengan penelitian Halim (2012) bahwa komitmen organisasi berpengaruh positif terhadap kinerja. Karyawan yang bekerja berdasarkan komitmen relatif bertahan dalam organisasi karena membutuhkan

\section{$H_{5}$ : Komitmen organisasi berpengaruh signifikan positif terhadap kinerja pemerintah desa}

Sumber daya manusia adalah kemampuan terpadu dari daya pikir dan daya fisik yang dimiliki individu. Perilaku dan sifatnya ditentukan oleh keturunan dan lingkungannya, 
sedangkan prestasi kerjanya di motivasi oleh keinginan untuk memenuhi kepuasannya ( Marnis, 2008: 18). Warisno (2009) menjelaskan bahwa sumber daya manusia berpengaruh terhadap kinerja pemerintah desa, artinya sumber daya manusia harus dikelola sebaik mungkin akan memberikan kontribusi secara optimal dalam pencapaian organisasi. Demikian penelitian Rulyanti (2014) bahwa sumber daya manusia berpengaruh terhadap kinerja.

\section{$H_{6}$ : Sumber Daya Manusia berpengaruh signifikan positif terhadap kinerja pemerintah desa}

Pengelolaan Keuangan Desa merupakan hal yang sangat penting yang harus dilaksanakan oleh aparatur desa, dimana untuk meningkatkan kinerja Pemerintah Desa salah satunya adalah dengan melakukan Pengelolaan Keuangan Desa secara lebih transaparan, akuntabel, dan partisipatif serta sesuai dengan peraturan yang berlaku. Dalam pengelolaan keuangan daerah, pengembangan sistem yang menunjang memerlukan suatu perencanaan dan pengimplementasian yang lebih hati-hati, guna menghindari penolakan terhadap sistem yang dikembangkan. Suatu keberhasilan implementasi sistem tidak hanya ditentukan oleh faktor teknis belaka, namun juga ditentukan oleh faktor kompetensi aparatur, pemahaman sistem akuntansi keuangan daerah, dan pengawasan internal, sehingga pengelolaan keuangan daerah dapat dikelola denganbaik sesuai dengan perundang-undangan yang berlaku ( Sugeng, 2014). Hasil penelitian Sugeng (2014) bahwa pengelolaan keuangan desa berpengaruh terhadap kinerja pemerintah desa.

\section{$H_{7}$ : Pengelolaan keuangan desa berpengaruh signifikan positif terhadap kinerja pemerintah desa}

\section{METODE PENELITIAN}

Penelitian ini untuk melihat hubungan beberapa variabel yang belum pasti. Peneliti menggunakan metode kuantitatif untuk menganalisi regulasi, komitmen organsasi dan sumber daya manusia terhadap kinerja pemerintah desa dengan pengelolaan keuangan desa sebagai variabel intervening. Populasi dalam penelitian ini berjumlah 60 orang yang terdiri dari seluruh aparatur desa yakni kepala desa sebagai pemegang kekuasaan pengelolaan keuangan desa, dan Pelaksana Teknis Pengelolaan Keuangan Desa (PTPKD) yang terdiri dari sekretaris desa, bendahara desa dan kepala seksi/kaur desa yang berada di Kecamatan Madiun, Kabupaten Madiun. Sampel adalah bagian dari jumlah dan karakteristik yang dimiliki oleh populasi tersebut (Sugiyono, 2017:137). Sampel dalam penelitian ini berjumlah 60 orang yang terdiri dari, Kepala Desa, Kepala Seksi/Kaur, Sekretaris Desa, Bendahara Desa, dan operator desa yang terlibat langsung dalam penelitian. Teknik pengambilan sampel dalam penelitian ini menggunakan sampling jenuh/sensus karena seluruh populasi dijadikan sampel, yakni sampel yang bila ditambah jumlahnya, tidak akan menambah keterwakilan sehingga tidak akan mempengaruhi nilai informasi yang akan diperoleh. Kriteria yang dimaksud sebagai berikut:

1. Terlibat langsung dalam pengelolaan keuangan desa

2. Telah bekerja pada Pemerintah Desa minimal 1 (satu) tahun, agar lebih memahami kondisi dan karakteristik masing-masing desa.

3. Pernah mengikuti diklat/bimbingan teknis/kursus/sosialisasi tentang pengelolaan keuangan desa yang diselenggarakan Pemerintah maupun Pemerintah Daerah.

Variabel dependen dalam penelitian adalah kinerja pemerintah desa, variabel interveing dalam penelitian ini adalah pengelolaan keuangan desa, untuk lebih jelasnya disajikan tabel definisi operasional variabel dibawah: 
Tabel 1. Operasionalisasi Variabel

\begin{tabular}{|c|c|c|c|c|}
\hline No & Variabel & Definisi & Indikator & Sumber \\
\hline 1 & $\begin{array}{l}\text { Regulasi } \\
\left(\mathrm{X}_{1}\right)\end{array}$ & $\begin{array}{lr}\text { Sekumpulan } & \text { peraturan } \\
\text { pemerintah } & \text { tentang } \\
\text { pengelolaan } & \text { keuangan } \\
\text { desa } & \end{array}$ & $\begin{array}{ll}\text { 1. } & \text { Ketersediaan regulasi } \\
\text { 2. } & \text { Sosialisasi } \\
\text { 3. } & \text { Pemahaman } \\
\text { 4. Kemudahan pelaksanaan } \\
\text { 1. Respon terhadap organisasi } \\
\text { 2. Ketersediaan dukungan } \\
\text { Peraturan Daerah terhadap } \\
\text { regulasi pusat } \\
\text { 3. Keterkaitan satu regulasi dengan } \\
\text { regulasi lainnya }\end{array}$ & $\begin{array}{l}\text { Rulyanti } \\
\text { (2017) }\end{array}$ \\
\hline 2 & $\begin{array}{l}\text { Komitme } \\
\mathrm{n} \\
\text { Organisa } \\
\text { si } \\
\left(\mathrm{X}_{2}\right)\end{array}$ & $\begin{array}{lr}\begin{array}{l}\text { Seberapa } \\
\text { pemerintah }\end{array} & \text { jauh } \\
\text { memiliki kemauan } & \text { dan } \\
\text { kesadaran, } & \text { serta } \\
\text { berkomitmen } & \text { dalam } \\
\text { menjalankan } & \\
\text { taggungjawab } & \text { dan } \\
\text { tugasnya. } & \end{array}$ & $\begin{array}{l}\text { 1. Bekerja keras } \\
\text { 2. Peduli terhadap nasib organisasi } \\
\text { 3. Senang bekerja pada organisasi } \\
\text { ini } \\
\text { 4. Kesamaan nilai } \\
\text { 5. Bekerja melampaui target }\end{array}$ & $\begin{array}{l}\text { Rulyanti } \\
\text { (2017) } \\
\text { Warisno } \\
\text { (2009) }\end{array}$ \\
\hline 3 & $\begin{array}{l}\text { Sumber } \\
\text { Daya } \\
\text { Manusia } \\
\left(X_{3}\right)\end{array}$ & $\begin{array}{l}\text { Kemampuan perangkat } \\
\text { desa dalam } \\
\text { melaksanakan tugasnya } \\
\text { berdasarkan pemahaman } \\
\text { tugas, kesiapan } \\
\text { melakukan perubahan } \\
\text { pengelolaan keuangan } \\
\text { desa, pelatihan dan latar } \\
\text { belakang pendidikan }\end{array}$ & $\begin{array}{l}\text { 1. Mempunyai Komitmen yang } \\
\text { tinggi } \\
\text { 2. Memiliki kompetensi } \\
\text { 3. Terampil, kreatif dan inovatif } \\
\text { 4. Disiplin dalam bekerja } \\
\text { 5. Memaksimalkan efisiensi, } \\
\text { kualitas dan produktivitas }\end{array}$ & $\begin{array}{l}\text { Rulyanti } \\
\text { (2017) } \\
\text { Warisno } \\
\text { (2009) }\end{array}$ \\
\hline 4 & $\begin{array}{l}\text { Kinerja } \\
\text { Pemerint } \\
\text { ah Desa } \\
\text { (Y) }\end{array}$ & $\begin{array}{l}\text { Kinerja perangkat desa } \\
\text { yang membantu kepala } \\
\text { desa. }\end{array}$ & $\begin{array}{l}\text { 1. Perencanaan } \\
\text { 2. Menjalin kerjasama dengan } \\
\text { mmitra kerja } \\
\text { 3. Menyelenggarakan } \\
\text { pengadministrasian pmerintah } \\
\text { 4. Pengelolaan keuangan desa } \\
\text { 5. Taat terhadap peraturan } \\
\text { perundang-undangan yang } \\
\text { berlaku }\end{array}$ & $\begin{array}{l}\text { Rulyanti } \\
\text { (2017) }\end{array}$ \\
\hline 5 & $\begin{array}{l}\text { Pengelol } \\
\text { aan } \\
\text { Keuanga } \\
\text { n Desa } \\
\text { (Y) }\end{array}$ & $\begin{array}{l}\text { Keseluruhan proses } \\
\text { pengelolaan keuangan } \\
\text { desa dimulai dengan } \\
\text { perencanaan, } \\
\text { pelaksanaan, } \\
\text { penatausahaan, } \\
\text { pelaporan dan } \\
\text { pertanggungjawaban }\end{array}$ & $\begin{array}{l}\text { 1. Pengelolaan keuangan desa } \\
\text { berdasarkan peraturan } \\
\text { perundang-undangan yang } \\
\text { berlaku. } \\
\text { 2. Menyusun Buku Kas Umum } \\
\text { dan Buku Bank. } \\
\text { 3. Pemungutan Pajak. } \\
\text { 4. Rekening Kas Desa. } \\
\text { 5. Menyertakan bukti-bukti yang } \\
\text { lengkap dan sah }\end{array}$ & $\begin{array}{l}\text { Rulyanti } \\
\text { (2017) }\end{array}$ \\
\hline
\end{tabular}


Analisis jalur digunakan jika secara teori kita yakin berhadapan dengan hubungan sebab dan akibat. Agar dapat menerangkan akibat langsung dan tidak langsung seperangkat variabel, sebagai variabel penyebab, terhadap variabel lainnya yang merupakan variabel akibat (Muhidin dan Abdurahman, 2007; 221). Diagram jalur menggambarkan secara grafis hubungan kausalitas antar variabel independen, dependen, intervening (Ghozali, 2018; 246). Penelitian ini menggunakan SPSS sebagai aplikasi pengujinya.

\section{HASIL DAN PEMBAHASAN}

Analisis data yang digunakan dalam penelitian ini menggunakan uji validitas, uji reabilitas, analisis deskriptif, uji regresi berganda, analisis jalur dan uji hipotesis dengan menggunakan SPSS for window version 16,0

\section{Uji Validitas}

Uji validitas digunakan untuk mengukur valid atau tidaknya suatu kuesioner. Kuesioner dapat dikatakan valid apabila pertanyaan pada kuesioner bisa menjelaskan sesuatu yang akan diukur. Uji validitas menggunakan tingkat signifikasi $5 \%$ dan $\mathrm{df}=\mathrm{n}-2$. Hasil pengolahan uji validitas diperoleh corrected item-total correlation harus lebih besar dari 0,254 dengan df 60-2 $=58$, tingkat signifikasi 5\%. Seluruh item pertanyaan terdiri dari 7 item pernyataan untuk Regulasi $\left(\mathrm{X}_{1}\right), 5$ item Komitmen Organisasi $\left(\mathrm{X}_{2}\right)$, 5 item Sumber Daya Manusia, 5 item Pengelolaan Keuangan Desa (Z), dan 5 item Kinerja Pemerintah Desa (Y). Dari hasil perhitungan koefisien korelasi $\left(\mathrm{r}_{\mathrm{xy}}\right)$ semuanya mmiliki $\mathrm{r}_{\text {hitung }}$ yang lebih besar dari $\mathrm{r}$ tabel $(0,254)$. Dengan ini disimpulkan bahwa seluruh item pertanyaan dinyatakan valid dan layak sebagai instrumen untuk mengukur data penelitian.

\section{Uji Reliabilitas}

Uji reliabilitas digunakan untuk mengukur kuesioner berupa indikator dari variabel dan mengetahui sejauh mana memiliki hasil yang sama meskipun telah dilakukan berulang-ulang. Kuesioner dikatakan reliabel apabila jawaban responden konsisten dari waktu ke waktu. Uji reliabilitas dilakukan dengan teknik Cronbach Alpha ( $\alpha$ ). Apabila Cronbach Alpha $\geq 0,60$ maka data dapat dikatakan reliabel, namun jika Cronbach Alpha $<0,60$ maka data tidak reliabel. Dari hasil uji reliabilitas diperoleh koefisien reliabilitas alpha sebesar 0,853 untuk regulasi $\left(\mathrm{X}_{1}\right), 0.836$ untuk komitmen organisasi $\left(\mathrm{X}_{2}\right), 0.757$ untuk sumber daya manusia $\left(\mathrm{X}_{3}\right)$, 0.705 untuk pengelolaan keuangan desa $(\mathrm{Z})$ dan 0,768 untuk kinerja pemerintah desa. Variabel di atas dapat dinyatakan reliabel karena koefisien lebih besar dari nilai Cronbach Alpha 0,60. Dan bisa ditarik kesimpulan bahwa ke lima hasil analisis reabilitas diatas dan secara menyeluruh kuesioner yang digunakan dalam penelitian ini dinyatakan reliabel.

\section{Statistik Deskriptif}

Statistik deskriptif memberikan gambaran tentang suatu data yang dilihat dari standar deviasi, mean varian, maksimum, minimum, sum, ranga, kurtois dan sebagainya dari masingmasing variabel. Variabel yang digunakan meliputi Regulasi $\left(\mathrm{X}_{1}\right)$, Komitmen Organisasi $\left(\mathrm{X}_{2}\right)$, Suber Daya Manusia $\left(\mathrm{X}_{3}\right)$, Pengelolaan Keuangan Desa $(\mathrm{Z})$, Kinerja Pemerintah Desa (Y). Dari tiga variabel dependen, satu variabel intervening da satu dari variabel independen. Variabel Regulasi $\left(\mathrm{X}_{1}\right)$ menunjukkan nilai rata-rata 4,30 Hal ini artinya kebanyakan responden memberikan pernyataan setuju pada setiap pertanyaan yang disajikan, artinya bahwa perangkat desa di Kecamatan Madiun setuju dengan regulasi yang sedang dijalankan pemerintah. Variabel Komitmen Organisasi $\left(\mathrm{X}_{2}\right)$, jawaban perangkat desa menunjukkan ratarata sebesar 4,07. Hal ini berarti banyak perangkat desa yang memberikan jawaban setuju pada setiap pertanyaannya, yang berarti perangkat desa di Kecamatan Madiun menunjukkan 
bahwa komitmen seseorang dalam suatu organisasi sangat diperlukan dan dianggap penting. Variabel Sumber Daya Manusia $\left(\mathrm{X}_{3}\right)$, jawaban perangkat desa menunjukkan rata-rata sebesar 4,12. Hal ini banyak yang memilih jawaban setuju dalam kuesioner yang telah diberikan. Artinya adanya Sumber Daya Manusia sangat diperlukan dalam melakukan hal yang berhubungan dengan pengelolaan keuangan desa. Variabel Pengelolaan Keuangan Desa (Z), Jawaban perangkat desa menunjukkan rata-rata 4,13 . Hal ini banyak yang memberikan jawaban setuju pada kuesioner yang telah diberikan. Dengan nilai rata-rata yang hampir mendekati nilai 5, ini berarti aparatur desa secara benar dan tepat telah melakukan pengelolaan keuangan desa dengan baik dan benar sesuai dengan prosedur yang berlaku. Variabel Kinerja (Y), jawaban perangkat desa menunjukkan rata-rata sebesar 4,17. Hal ini banyak yang memberikan jawaban setuju pada kuesioner yang telah diberikan. Dengan nilai rata-rata yang hampir sempurna, ini berarti aparatur desa di Kecamata Madiun memiliki kinerja, loyalitas yang cukup tinggi terhadap suatu organisasi. Hasil analisis dengan menggunakan statistik deskriptif terhadap regulasi $\left(\mathrm{X}_{1}\right)$, komitmen organisasi $\left(\mathrm{X}_{2}\right)$, sumber daya manusia $\left(\mathrm{X}_{3}\right)$, pengelolaan keuangan desa $(\mathrm{Z})$, dan kinerja pemerintah desa $(\mathrm{Y})$ menunjukkan nilai minimum dari semua variabel 3 dan nilai maksimum 5. Hal ini menunjukkan bahwa dari semua pertanyaan yang diberikan, para aparatur desa menjawab tidak tahu, dan sangat setuju.

\section{Analisis Jalur (Path Analysis) dan Diagram Jalur (Path Diagram) Persamaan Struktural Jalur pertama}

Jalur pertama struktur ini menjelaskan tentang Regulasi $\left(\mathrm{X}_{1}\right)$, Komitmen Organisasi $\left(\mathrm{X}_{2}\right)$, Sumber Daya Manusia $\left(\mathrm{X}_{3}\right)$ terhadap Pengelolaan Keuangan Desa $(\mathrm{Z})$. Setelah membuat persamaan jalur pertama, maka langkah selanjutnya menguji regresi berganda. Regresi Jalur 1 pada bagian tabel koefisien dapat diketahui bahwa nilai signifikansi dari ketiga variabel yaitu Regulasi $\left(X_{1}\right)=0,001$, Komitmen Organisasi $\left(X_{2}\right)=0,229$ dan Sumber Daya Manusia $\left(X_{3}\right)=$ 0,000. Variabel Regulasi $\left(\mathrm{X}_{1}\right)$ dan Sumber Daya Manusia $\left(\mathrm{X}_{3}\right)$ memiliki nilai signifikansi lebih kecil dari 0,05. Sedangkan variabel Komitmen Organisasi $\left(\mathrm{X}_{2}\right)$ memiliki nilai signifikansi diatas 0,05. Sehingga hasil ini memberikan kesimpulan bahwa Regresi jalur 1, yakni variabel Regulasi $\left(\mathrm{X}_{1}\right)$ dan Sumber Daya Manusia $\left(\mathrm{X}_{3}\right)$ berpengaruh signifikan terhadap Pengelolaan $(\mathrm{Z})$. Namun, Komitmen Organisasi $\left(\mathrm{X}_{2}\right)$ tidak berpengaruh signifikan terhadap Pengelolaan (Z). Besarnya nilai $\mathrm{R}$ Square sebesar 0,525. Untuk mendapatkan $\varepsilon_{1}$ dapat dicari dengan rumus $\varepsilon_{1}=\sqrt{(1-0,499)}=0,707$. Dengan ini maka diperoleh diagram jalur 1 sebagai berikut $\mathrm{Y}=-0,333 \mathrm{X}_{1}+0,137 \mathrm{X}_{2}+0,607 \mathrm{X}_{3}+0,707$

\section{Persamaan Struktural Jalur kedua}

Jalur kedua struktur ini menjelaskan tentang Regulasi $\left(\mathrm{X}_{1}\right)$, Komitmen Organisasi $\left(\mathrm{X}_{2}\right)$, Sumber Daya Manusia $\left(\mathrm{X}_{3}\right)$ terhadap Kinerja Pemerintah Desa (Y). Setelah membuat persamaan jalur kedua, maka langkah selanjutnya menguji regresi berganda. Regresi Jalur 2 pada bagian tabel koefisien dapat diketahui bahwa nilai signifikansi dari ketiga variabel yaitu Regulasi $\left(\mathrm{X}_{1}\right),=0,642$, Komitmen Organisasi $\left(\mathrm{X}_{2}\right),=0,157$ dan Sumber Daya Manusia $\left(\mathrm{X}_{3}\right)$ $=0,000$. Variabel tentang Regulasi $\left(X_{1}\right)$ dan Komitmen Organisasi $\left(X_{2}\right)$, tidak bersignifikansi diatas dari 0,05. Sedangkan variabel Sumber Daya Manusia $\left(X_{3}\right)$ memiliki nilai signifikansi dibawah 0,05. Sehingga hasil ini memberikan kesimpulan bahwa Regresi jalur 2, yakni variabel Regulasi $\left(\mathrm{X}_{1}\right)$ dan Komitmen Organisasi $\left(\mathrm{X}_{2}\right)$, tidak berpengaruh signifikan terhadap Kinerja Pemerintah Desa (Y). Namun, Sumber Daya Manusia $\left(\mathrm{X}_{3}\right)$ berpengaruh signifikan terhadap Kinerja Pemerintah Desa (Y). Untuk mendapatkan $\varepsilon_{2}$ dapat dicari dengan rumus $\varepsilon_{2}$ $=\sqrt{ }(1-0,376)=0,789$. Dengan ini maka diperoleh diagram jalur 2 sebagai berikut $Y=-0,51$ $\mathrm{X}_{1}+0,180 \mathrm{X}_{2}+0,535 \mathrm{X}_{3}+0,789$ 


\section{Persamaan Struktural Jalur ketiga}

Jalur ketiga struktur ini menjelaskan tentang pengelolaan $(Z)$ terhadap kinerja pemerintah desa (Y). Setelah membuat persamaan jalur ketiga, maka langkah selanjutnya menguji regresi berganda. Regresi Jalur 3 pada bagian tabel koefisien dapat diketahui bahwa nilai signifikansi dari variabel Pengelolaan Keuangan Desa (Z) sebesar 0,000. Variabel Pengelolaan Keuangan Desa $(Z)$ memiliki tingkat signifikansi dibawah dari 0,05. Sehingga hasil ini memberikan kesimpulan bahwa Regresi jalur 3, Variabel Pengelolaan Desa (Z) berpengaruh signifikan terhadap Kinerja Pemerintah Desa (Y). Dengan ini maka diperoleh diagram jalur 2 sebagai berikut $\mathrm{Z}=0,464 \mathrm{Y}+\varepsilon_{2}$

\section{Koefisien Determinasi}

Nilai koefisien determinasi menunjukkan nilai $R$ Square dari model regresi digunakan untuk megetahui berapa besarnya indeks pengelolaan keuangan desa yang dapat dijelaskan oleh variabel bebas dan terikat. Nilai Adjusted $\mathrm{R}^{2}$ jalur 1 sebesar 0,499 menunjukkan bahwa pengaruh variabel regulasi, komitmen organisasi, SDM terhadap pengelolaan. Hal ini menunjukkan bahwa kontribusi pengaruh Regulasi $\left(\mathrm{X}_{1}\right)$, Komitmen Organisasi $\left(\mathrm{X}_{2}\right)$, Sumber Daya Manusia $\left(\mathrm{X}_{3}\right)$ terhadap Pengelolaan Keuangan Desa $(Z)$ sebesar 49,9\% dan sisannya 50,1\% merupakan kontribusi dari kinerja pemerintah desa yang tidak dimasukkan. Nilai Adjusted $\mathrm{R}^{2}$ jalur 2 sebesar 0,376 menunjukkan bahwa pengaruh variabel $\mathrm{r}$ Regulasi $\left(\mathrm{X}_{1}\right)$, Komitmen Organisasi $\left(\mathrm{X}_{2}\right)$, Sumber Daya Manusia $\left(\mathrm{X}_{3}\right)$ terhadap Kinerja Pemerintah Desa (Y). Hal ini menunjukkan bahwa kontribusi pengaruh Regulasi $\left(\mathrm{X}_{1}\right)$, Komitmen $\left(\mathrm{X}_{2}\right)$, Sumber Daya Manusia $\left(\mathrm{X}_{3}\right)$ terhadap Kinerja Pemerintah Desa $(\mathrm{Y})$. sebesar 37,6\% dan sisannya $62,4 \%$ merupakan kontribusi dari pengelolaan kuangan desa yang tidak dimasukkan. Nilai Adjusted R Square jalur 3 sebesar 0,202. Hal ini menunjukkan bahwa kontribusi pengaruh Pengelolaan Keuangan Desa (Z) terhadap Kinerja Pemerintah Desa (Y) sebesar 20,2\% dan sisannya $79,8 \%$ merupakan kontribusi dari regulasi, komitmen organisasi, sumber daya manusia yang tidak dimasukkan.

\section{Uji $F$}

Hasil Uji F Jalur 1 menunjukkan hasil pengujian secara simultan variabel dalam penelitian yaitu Regulasi $\left(\mathrm{X}_{1}\right)$, Komitmen Organisasi $\left(\mathrm{X}_{2}\right)$, Sumber Daya Manusia $\left(\mathrm{X}_{3}\right)$, berpengaruh signifikan terhadap Pengelolaan Keuangan Desa (Z) .Hasil Uji F Jalur 2 sebesar 12,843 dengan signifikansi sebesar 0,000. Hasil ini menunjukkan hasil pengujian secara simultan variabel dalam penelitian yaitu Regulasi $\left(\mathrm{X}_{1}\right)$, Komitmen Organisasi $\left(\mathrm{X}_{2}\right)$, Sumber Daya Manusia $\left(\mathrm{X}_{3}\right)$ berpengaruh signifikan terhadap Kinerja Pemerintah Desa (Y). Hasil Uji F Jalur 3 sebesar 15,923 dengan signifikansi sebesar 0,000. Hasil ini menunjukkan hasil pengujian secara simultan variabel dalam penelitian yaitu pengelolaan (Z) berpengaruh signifikan terhadap kinerja (Y). Artinya, Pengelolaan keuangan dana desa menjadi aspek penting dan mendasar yang harus dimiliki para pemerintah desa khususnya aparat perangkat desa dalam mewujudkan transparansi dan akuntabilitas keuangan desa. Prinsip ini dimulai dari tahap perncanaan sampai dengan pelaporan dan pertanggungjawaban keuangan desa dan tugas serta tanggungg jawab para pejabat pengelola. Berdasarkan teori agensi. Teori agenprinsipal menganalisa susunan kotraktual antara kelompok, organisasi atau dua individu atau lebih. Prinsipal membuat suatu kontrak, baik secara ekspisit atau implisit dengan agent, berharap agent akan melakukan pekerjaan seperti yang diminta prinsipal dalam hal pendelegasian wewenang. (Halim dan Abdullah, 2006). 


\section{Uji T}

\section{Regulasi Berpengaruh Signifikan Terhadap Pengelolaan Keuangan Desa}

Regulasi sangat berperan penting dalam pengelolaan keuangan desa secara keseluruhan. Dengan regulasi dari berbagai Undang-Undang yang bertujuan agar memudahkan dalam pelaksanaannya dan tidak menimbulkan multitafsir dalam penerapannyan (Haryanto, 2002). Pengelolaan keuangan desa diatur sesuai dengan regulasi yang berlaku. Peraturan perundangundangan berpengaruh positif terhadap pengelolaan keuangan daerah. Hasil pengujian ini menunjukkan nilai signifikan 0,001 < ),05 dapat disimpulkan bahwa regulasi berpengaruh secara postif terhadap pengelolaan keuangan desa menunjukkan arah semakin tinggi. Maka, $\mathrm{H}_{1}$ diterima. Hasil penelitian ini mendukung penelitian Haryanto(2007) dan menolak penelitian Rulyanti (2017). Hasil diatas menunjukkan bahwa regulasi sangat berperan penting terhadap pengelolaan keuangan desa. Regulasi berfungsi sebagai pedoman dalam mejaankan pengelolaan keuangan desa. Banyaknya peraturan yang mengatur tentang pengelolaan keuangan desa merupakan suatu bukti nyata bahwa regulasi sangat diperlukan dan tidak jarang dilakukan pembaharuan. Permendagri Nomor 113 Tahun 2014 tentang pengelolaan keuangan desa. Permendagri Pengelolaan Keuangan Desa terdiri dari Bab-bab tentang Ketentuan Umum, Asas Pengelolaan Keuangan Desa, Kekuasaan Pengelolaan Keuangan Desa, APBDes, Pengelolaan, Pembinaan dan Pengawasan. Melanggar regulasi nantinya akan berhadapan dengan hukum. Tugas dan tanggung jawab untuk mengelola keuangan desa akan berhubungan erat dan akan menentuka nasip rakyat desa. APBDesa untuk sebesar-besarnya kesejahteraan rakyat.dan nantinya kita lihat apakah desa-desa kita akan menjadi desa yang maju dan rakyatnya sejahtera dimasa yang akan datang, itu di tentukan sejauh mana etika pengelolaan keuangan di pegang teguh para pengelola keuangan desa.

\section{Komitmen Organisasi Tidak Berpengaruh Signifikan Terhadap Pengelolaan Keuangan Desa}

Hasil penelitian ini menunjukkan bahwa Komitmen Organisasi tidak mempunyai pengaruh yang signifikan terhadap pengelolaan keuangan desa. Nilai signifikansi komitmen organisasi dapat dikatakan relatif besar. Perubahan besarnya nilai di variabel komitmen organisasi terhadap pengelolaan keuangan desa sifatnya tidak terstruktur dan tidak konsisten, hal ini membuat komitmen organisasi tidak mempunyai pengaruh yang signifikan terhadap pengelolaan keuangan desa. Hasil pengujian ini menunjukkan nilai signifikansi 0,229>0,05 dapat disimpulkan bahwa komitmen organisasi tidak berpengaruh signifikan terhadap pengelolaan keuangan desa. Maka $\mathrm{H}_{2}$ ditolak. Hasil penelitian ini menentang hasil dari Rulyanti (2017), Halim (2012) dan mendukung hasil penelitian Warisno (2009). Hasil di atas menunjukkan bahwa memiliki komitmen saja belum cukup untuk melakukan pengelolaan keuangan desa. Dalam melakukan pengelolaan keuangan desa aparatur desa harus memiliki rasa tanggung jawab yang besar, mematuhi regulasi yang berlaku, dan memiliki pengetahuan yang baik tentang pengelolaan keuangan desa. Tidak memilik komitmen organisasi untuk melakukan pengelolaan keuangan desa banyak terjadi di Indonesia, banyaknya operasi tangkap tangan para pejabat pemerintah desa sebagi bukti nyata bahwa komitmen organisasi tidak berjalan dengan baik.

\section{Sumber Daya Manusia Berpengaruh Signifikan Positif Terhadap Pengelolaan Keuangan}

Sumber daya manusia Sumber daya manusia adalah kemampuan terpadu dari daya pikir dan daya fisik yang dimiliki individu. Perilaku dan sifatnya ditentukan oleh keturunan dan lingkungannya, sedangkan prestasi kerjanya di motivasi oleh keinginan untuk memenuhi kepuasannya (Priyono \& Marnis, 2008: 18). Kapasitas perangkat desa dalam menyusun regulasi baik, baik dalam hal perencanaan, pelaksanaan, maupun penyusunan Peraturan Desa dan Peraturan Kepala Desa masih kurang. Hal ini menunjukkan bahwa sumber daya manusia 
sangat berpengaruh terhadap pengelolaan keuangan desa (Rulyantti, 2017). Hasil pengujian menunjukkan nilai signifikansi $0,000<0,05$ dapat disimpulkan bahwa sumber daya manusia berpengaruh secara signifikan positif terhadap pengelolaan keuangan desa. Maka $\mathrm{H}_{3}$ diterima. Hasil penelitian ini mendukung penelitian Rulyanti (2017), Warisno (2009) dan menolak penelitian Idris dan Konadi (2012). Hasil diatas menujukkan semakin tingginya banyaknya sumber daya manusia yang berkompeten, semakin baik pula pengelolaan keuangan desa. Dalam melakukan penyusunan, pelaporan dan pertanggungjawaban tidak lepas halnya dilakukan oleh manusia. Itu semua dapat teradi karena para pejabat pemerintah desa sudah banyak yang berpendidikan tinggi ada yang samppa S2.

\section{Regulasi Tidak Berpengaruh Signifikan Terhadap Kinerja Pemerintah Desa}

Hasil penelitian ini menunjukkan bahwa Regulasi tidak mempunyai pengaruh yang signifikan terhadap kinerja pemerintah desa.. Nilai signifikansi regulasi dapat dikatakan relatif besar. Perubahan besarnya nilai di variabel regulasi terhadap kinerja pemerintah desa sifatnya tidak terstruktur dan tidak konsisten, hal ini membuat regulasi tidak mempunyai pengaruh yang signifikan terhadap kinerja pemerintah desa. Hasil pengujian menunjukkan nilai signifikansi 0,642 < 0,05 dapat disimpulkan bahwa regulasi tidak berpengaruh secara signifikan terhadap kinerja pemerintah desa. Maka $\mathbf{H}_{\mathbf{4}}$ ditolak. Hasil penelitian ini mendukung penelitian Rulyanti (2017), dan menolak penelitian Idris dan Konadi (2012). Hasil di atas menjelaskan bahwa regulasi tidak berperan penting terhadap kinerja pemerintah desa. Dalam hal ini aparatur desa masih mengalami kesulitan dalam memahami regulasi yang berlaku. Dalam menjalankan tugasnya aparatur desa belum sepenuhnya menerapkan regulasi yang berlaku.

\section{Komitmen Organisasi Tidak Berpengaruh Signifikan Terhadap Kinerja Pemerintah Desa}

Hasil penelitian ini menunjukkan bahwa Komitmen Organisasi tidak mempunyai pengaruh yang signifikan terhadap Kinerja Pemerintah Desa. Nilai signifikansi komitmen organisasi dapat dikatakan relatif besar. Perubahan besarnya nilai di variabel komitmen organisasi terhadap kinerja Pemerintah Desa sifatnya tidak terstruktur dan tidak konsisten, hal ini membuat komitmen organisasi tidak mempunyai pengaruh yang signifikan terhadap kinerja. Hasil pengujian menunjukkan nilai signifikansi $0,157<0,05$ dapat disimpulkan bahwa komitmen organisasi tidak berpengaruh secara signifikan terhadap kinerja pemerintah desa. Maka $\mathrm{H}_{5}$ ditolak. Hasil penelitian ini mendukung penelitian Warisno (2009) dan menolak penelitian Rulyanti (2017). Hal ini menjelaskan bahwa komitmen terhadap kinerja sangat kurang. Dengan komitmen aparatur desa diharapkan bisa menyelesaikan pekerjaannya cepat, tepat, dan benar. Namun pada hasil penelitian ini di dapati bahwa ada beberapa aparatur desa hanya bekerja dan kurang memiliki rasa senang dalam bekerja di suatu organisasi.

\section{Sumber Daya Manusia Berpengaruh Positif Terhadap Kinerja Pemerintah Desa}

Sumber daya manusia Sumber daya manusia adalah kemampuan terpadu dari daya pikir dan daya fisik yang dimiliki individu. Perilaku dan sifatnya ditentukan oleh keturunan dan lingkungannya, sedangkan prestasi kerjanya di motivasi oleh keinginan untuk memenuhi kepuasannya (Priyono \& Marnis, 2008: 18). Hasil pengujian menunjukkan nilai signifikansi $0,000<0,05$ dapat disimpulkan bahwa sumber daya manusia berpengaruh secara signifikan terhadap kinerja pemerintah desa. Maka $\mathrm{H}_{6}$ diterima. Hasil penelitian ini mendukung penelitian Rulyanti (2017), Warisno (2009). Hal ini menjelaskan apabila sumber daya manusia semakin baik maka kinerja pemerintah akan semakin baik pula. Sumber daya manusia merupakan elemen organisasi yang sangat penting, karenanya harus dipastikan sumber daya manusia ini harus dikelola sebaik mungkin akan mampu memberikan kontribusi 
secara optimal dalam upaya pencapaian tujuan organisasi (Warisno,2009).

\section{Pengelolaan Keuangan Desa Berpengaruh Positif terhadap Kinerja Pemerintah Desa}

Suatu keberhasilan implementasi sistem tidak hanya ditentukan oleh faktor teknis belaka, namun juga ditentukan oleh faktor kompetensi aparatur, pemahaman sistem akuntansi keuangan daerah, dan pengawasan internal, sehingga pengelolaan keuangan daerah dapat dikelola dengan baik sesuai dengan perundang-undangan yang berlaku, Sugeng (2014).Hasil pengujian menunjukkan nilai signifikansi $0,000<0,05$ dapat disimpulkan bahwa pengelolaan keuangan desa berpengaruh secara signifikan terhadap kinerja pemerintah desa. Maka $\mathrm{H}_{7}$ diterima. Hasil penelitian ini mendukung penelitian Rulyanti (2017) dan Sugeng (2014). Hal ini menunjukkan bahwa Kecamatan Madiun dalam melakukan pengelolaan keuangan desa sesuai dengan regulasi yang berlaku. Suatu sistem pengelolaan yang baik di mulai dari suatu perencanaan dan pengimplementasian secara hati-hati. Suatu keerhasilan tidak hanya ditetukan oleh faktor teknis, namun juga ditentukan faktor regulasi, komitmen organisasi, dan sumber daya manusia.

\section{KESIMPULAN}

Berdasarkan pembahasan hasil penelitian tentag faktor yang mempengruhi pengelolaan keuangan desa terhadap kinerja pemerintah desa di Kecmatan Madiun, Kabupaten Madiun. Maka, dapat disimpulkan bahwa regulasi, komitmen organisasi, sumber daya manusia,pengelolaan keuangan desa, kinerja pemerintah desa pada umunya cukup baik, namun masih terdapat hal-hal yang belum sepenuhnya berjalan dengan baik. Seperti masih kurangnya komitmen organisasi terhadap pengelolaan keuangan desa, regulasi yang digunakan untuk kinerja pemerintah desa.

Untuk mengatasi hambatan yangterjadi, pemerintah desa di kecamatan madiun sering melakukan sosialisasi mengenai regulasi yang dapat memperbaiki performa kinerja pejabat pemerintah desa. Serta memperbaiki komitmen organisasi yang harus dimiliki pejabat pemerintah desa yang diantarannya disiplin, ulet dan loyalitas terhadap organisasi.

\section{DAFTAR PUSTAKA}

BAPPENAS. 2014. NAWACITA pemerintah yang ada di dalam rencana jangka menengah Nasional 2015-2019. Jakarta: Badan Perencanaan Pembangunan Nasional (BAPPENAS)

BPKP. 2015. Warta pengawasan: Kawal keuangan desa. Edisi HUT ke-70 RI. Volume XXII

Halim, R. 2012. Pengaruh komitmen organisasi dan peranan kepemimpinan dalam meningkatkan pengelolaan keungan daerah pada dinas pendapatan, pengelolaan keuangan dan asset Kabupaten Banggai Kepulauan. Jurnal Academia Fisip Untad. ISSN 1411-3341, 04 (01).

Haryani \& Syafruddin. 2010.Kepercayaan dan implementasi peraturan dan perundangundangan penyusunan dan pengelolaan keuangan daerah di Kabupaten Batang. Simposium Nasional Akuntansi XIII. Sekolah Tinggi Ilmu Ekonomi (STIE) dan Universitas Diponegoro.

Haryanto. 2007. Akuntansi sektor publik. Semarang: Badan Penerbit Universitas Diponegoro.

Idris, A. \& Konadi, W. 2012. Pengaruh regulasi dan ketersediaan anggaran terhadap kinerja pelayanan aparatur SKPD dan implikasinya pada kualitas pelayanan publik di provinsi Aceh. ISSN: 2089-59171, 1(1).

Jensen, M.C. \& Meckling.,W.H., 1976, Theory of the firm: Managerial behavior, agency cost, 
and ownership structure, Jurnal of Financial Economics, 3(4),305-360.

Kementerian Keuangan Republik Indonesia dalam sosialisasi undang-undang desa

Kepmendagri No 903-057 Tahun 1988 tentang penyempurnaan bentuk dan susunan anggaran pendapatan daerah masuk dalam pos penerimaan pembangunan

Keputusan Kepala Lembaga Administrasi Negara No : 239/IX/6/8/2003

Pasal 13 ayat 1 UU no 5 Tahun 1975 tentang pokok pokok pemerintahan

Pasal 33 Peraturan Pemerintah Nomor 6 Tahun 1975 tentang peraturan pemerintah

Peraturan Menteri Dalam Negeri No 113 Tahun 2014 tentang pengelolaan keuangan desa

Peraturan Pemerintah No 6 Tahun 1975 dan Keputusan Mendagri no 3 Tahun 1999

Peraturan Pemerintah Nomor 60 Tahun 2014 tentang dana desa

Peraturan Presiden Nomor 131 Tahun 2015 Tentang penetapan daerah tertinggal tahun 20152019 Permendagri No 13 Tahun 2006 ttentang pedoman pengelolaan keuangan

Permendagri Nomor 113 Tahun 2014 tentang pengelolaan keuangan desa

PP Nomor 43 Tahun 2014 tentang peraturan pelaksanaan UU Desa

Rulyanti, Dina. 2017. Faktor - faktor yang mempengaruhi kinerja pemerintah desa melalui pengelolaan keuangan desa sebagai variabel intervening. Jurnal Bisnis dan Manajemen. 11(03).

Sugeng. 2014. Faktor-faktor yang mempengaruhi pengelolaan keuangan daerah dan implikasinya terhadap kinerja pemerintah daerah di Kabupaten Kediri. Jurnal Riset Ekonomi dan Bisnis, 1(2).

Sunarti, N. 2018. Pengelolaan keuangan desa dan sistem akuntansi keuangan desa dalam rangka meningkatkan kinerja Pemerintah Desa Pacung. Jurnal Ilmiah Akuntansi dan Humanika, 8(1). 